\title{
Chemistry and Giftedness: A Delight Full and Catalytic Mixture in a Home Enrichment Model
}

\author{
Kelling Cabral Souto1,2, Mônica Braga Xavier², Helena Carla Castro3,4, \\ Cristina Maria Carvalho Delou ${ }^{3,4}$
}

\begin{abstract}
${ }^{1}$ Instituto Federal de Educação, Ciência e Tecnologia do Rio de Janeiro, Rio de Janeiro, Brasil
${ }^{2}$ PGCTIn, Instituto de Biologia, Universidade Federal Fluminense, Rio de Janeiro, Brasil

${ }^{3}$ PGCTIn, PPBI, CMPDI, Instituto de Biologia, Universidade Federal Fluminense, Rio de Janeiro, Brasil

${ }^{4}$ Programa de Pós-Graduação em Ensino em Biociências e Saúde, IOC, Fiocruz, Rio de Janeiro, Brasil

Email: kelling.souto@ifrj.edu.br, cristinadelou@id.uff.br
\end{abstract}

How to cite this paper: Souto, K. C., Xavier, M. B., Castro, H. C., \& Delou, C. M. C. (2022). Chemistry and Giftedness: A Delight Full and Catalytic Mixture in a Home Enrichment Model. Creative Education, 13, 112-127.

https://doi.org/10.4236/ce.2022.131008

Received: December 20, 2021

Accepted: January 16, 2022

Published: January 19, 2022

Copyright $\odot 2022$ by author(s) and Scientific Research Publishing Inc. This work is licensed under the Creative Commons Attribution-NonCommercial International License (CC BY-NC 4.0). http://creativecommons.org/licenses/by-nc/4.0/ (c) (i) (5) Open Access

\begin{abstract}
Considering the importance of an enriched environment to promote meaningful, autonomous and motivating learning for High Abilities or Gifted students (HA/Gs) and the gaps left by most schools worldwide in attending this public, this work described a model of home educational enrichment for $\mathrm{HA} / \mathrm{Gs}$ in the area of chemistry to improve their teaching process. The model takes into consideration the changes experienced lately in education during the pandemic situation of COVID-19, allowing to work at home on skills and competences, through a set of playful and educational activities, based on a chemical main theme. It requires minimal resources and knowledge as it uses everyday materials and concepts. The activities and results obtained with two children with High Abilities or Giftedness were encouraging. Throughout the process, the children were motivated, collaborative, creative and investigative. Learning took place in a participatory manner. The results demonstrate the feasibility of home enrichment and pointed it as a strategy to be used to promote education (supplementation) with this special needs group.
\end{abstract}

\section{Keywords}

Home Enrichment, High Abilities or Giftedness, Chemical

\section{Introduction}

Education has undergone profound changes over time. The teaching practice and the role of the teacher have been the subject of many discussions, in the search for improvements in the teaching-learning process and to meet the de- 
mands of the market and current students (Peres et al., 2013; Much, Bonfada, \& Terrazzan, 2018).

Technological advances and globalization are important and responsible for structural changes in sectors of society and consequently in education, causing the emergence of a new generation of students in classrooms.

Passarelli, Junqueira, \& Angeluci (2014) reflect the issue and state that from the beginning of the 2000s onwards a new generation of students became part of educational institutions. Students who were born immersed in the culture of new media and use them in a daily and natural way, very different from previous generations.

According to Education 4.0 (Hussin, 2018; Panagiotopolos \& Karanikola, 2020), which was created due to the advent of Industry 4.0, learning is built around the student, as the protagonist of the process. The student of Education 4.0 learns not only the necessary skills and knowledge, but also the source of these skills and knowledge. The student learns in a hands-on and collaborative process, while the teacher assumes the role of facilitator of learning (Garofalo, 2018).

Apprentice, mediator, advisor and researcher in the search for new practices, creating favorable circumstances, proposing and mediating actions that lead to student learning, are some of the roles that the 4.0 teacher must assume, according to Garofalo (2018). However, Garofalo (2018) emphasizes that to play such roles competently, the teacher needs to have well-defined goals and objectives, understanding the students' social historical context and the difficulties of the process.

According to Moran \& Bacich (2018), the traditional teaching model that has the teacher as the central figure needs to be revised, changing to a perspective of learning where the focus is on the student as an active agent of their learning. Moran \& Bacich (2018) also states that learning becomes more significant when students are especially involved in well balanced activities, challenges and contextualized information.

It is up to the teacher to look carefully at the students in order to involve them in school activities, always motivating and challenging them to a full and pleasurable learning. According to Kueth (1978) a motivated individual has a greater desire to reach his goals, since the goal itself encourages and drives him.

High Abilities or Gifted Students-HA/Gs are still challenges for their teachers to become more expressive in terms of providing an enriched, challenging and motivational educational environment (Brasil, 2001; Renzulli, 2014b). According to Renzulli's (1986, 2014a, 2014b) theory of three rings, HA/G occurs with the interaction of three traits, namely: above-average skill, involvement with the task and creativity.

The above-average ability (Renzulli \& Reis, 1997; Renzulli, 2014a, 2014b; Virgolim, 2014) translates as a superior potential compared to their peers in any area of human knowledge or in any of the intelligences defined by Gardner (1993, 1999). It manifests itself in the ability to process information, generate 
appropriate and creative responses to new situations, and have abstract thinking (Renzuli \& Reis, 1997).

Whereas creativity transposes through originality, the flow of ideas, thoughts, curiosities, desires for challenges and innovative actions in a specific area of performance (Renzulli \& Reis, 1997; Renzulli, 2014a, 2014b), the involvement with the task is closely linked to the individual's level of motivation, which translates into the release of energy in an activity in the specific performance area (Renzulli \& Reis, 1997; Renzulli, 2014a, 2014b).

According to Renzulli (2014a), the student who presents gifted behavior requires a special educational environment that meets their interests, talents and motivational levels, promoting the development of their potential and their creative production. These students need a wide variety of educational opportunities, resources and encouragement above and beyond those ordinarily provided through regular instructional programs (Renzulli, 2014a).

Concerned with the school attendance of students with HA/G in different educational environments, Renzulli publishes, together with the theory of the three rings, the Triadic Enrichment Model (Renzulli, 2014b; Worrell et al., 2019). It is a learning theory that seeks to encourage creative, intellectual talent and gifted behavior in all students with potential (Burns, 2014). The objective is to create opportunities for talent and increase the number of knowledge producers in society (Renzulli, 2014a).

In Brazil, from a legal point of view (Brasil, 1996, 2013, 2015), students with $\mathrm{HA} / \mathrm{G}$ are included in special education and are guaranteed, when necessary, specialized support services. The legislation also guarantees curricula, methods, techniques, educational resources, specific organizations to meet their needs, as well as acceleration of studies, education for work, early identification, technical and financial support by the government, among other requirements. However, the reality of educational assistance to HA/G students is far from the legislation, including aspects involving teacher education (Souto, Castro, \& Delou, 2021).

According to de Alencar \& Martins (2011), there are many obstacles to the promotion of an effective service by the school in Brazil and in much of the world to students with HA/G. The obstacles permeate, especially, teacher training (de Alencar \& Martins, 2011).

Scarce resources, limited time, heterogeneity among students are factors that also make it difficult to assist HA/G students. Martins, Cardoso, \& Delou (2016) argue that students are different from each other, and therefore, the time and space of classes are insufficient to meet the different demands between them.

The pandemic era of COVID-19 was, and still is in many countries, marked for the necessity of attending students at home with different views (positive and/or negative) of this experience (Petrie, 2020; Conejeros-Solar \& Smith, 2021; Musaddiq et al., 2021). Considering the inability of many schools in attending HA/G students worldwide (Sabatella \& Cupertino, 2007) and aiming on finding an attractive, creative and motivating learning experience method, this article 
described the development of a model of home enrichment for gifted people involving chemistry area, inspired by the Triadic Enrichment Model of Renzulli (2014b).

The goal is to report a successful practice of the enrichment model with children HA/G that took place through the application of a set of playful and pedagogical activities at home and by parents, under the supervision of researchers. By using an experimental strategy of learning by playing and a student hands-on approach, the model promotes a new proposal for supplementation, through an investigative methodology, which can inspire parents and educators around the world in the educational care of students with HA/G.

\section{Concepts and Methodology}

\subsection{Triadic Enrichment Model}

The Triadic Enrichment Model created by Renzulli (2014b) consists of three types of school enrichment, types I, II and III (Table 1). This enrichment model allows flexibility from the point of view of its stages according to the student's interest and maturity (Renzulli, 2014b; Burns, 2014; Virgolim, 2014). The student can start from any of the three types of enrichment, as well as return to any type and time whenever necessary. It is encouraged that enrichment types I and II be offered to larger groups of students and not just to HA/G, whereas type III is indicated for students who have awakened a particular interest in going deeper into a topic.

Table 1. Types of school enrichment from the triadic enrichment model created by Renzulli (2014b).

\begin{tabular}{cll}
\hline Type & \multicolumn{1}{c}{ Enrichment Strategy } & \multicolumn{1}{c}{ Purpose $^{*}$} \\
\hline & $\begin{array}{l}\text { It exposes students to a variety of } \\
\text { disciplines, themes, practitioners, } \\
\text { venues, lectures, events, etc. }\end{array}$ & $\begin{array}{l}\text { Student in contact with a variety of } \\
\text { information and questions so that } \\
\text { they can raise genuine interests } \\
\text { and later deepen their studies }\end{array}$ \\
& $\begin{array}{l}\text { It promotes the development of thinking } \\
\text { and feeling processes through materials } \\
\text { and methods, it allows training in task } \\
\text { execution, seeking to develop in the } \\
\text { student skills and competences for } \\
\text { investigative research, decision-making, } \\
\text { problem solving and critical-creative } \\
\text { thinking }\end{array}$ & $\begin{array}{l}\text { Focus on domains, skills and } \\
\text { content knowledge that provide } \\
\text { support to students to continue } \\
\text { their more advanced studies }\end{array}$ \\
$\begin{array}{l}\text { It stimulates studying a certain area } \\
\text { of knowledge in depth, researching, } \\
\text { solving real problems, developing } \\
\text { authentic products, promoting } \\
\text { autonomous learning, task commitment, } \\
\text { self-confidence and critical thinking }\end{array}$ & $\begin{array}{l}\text { Indicated for students who have } \\
\text { awakened a particular interest in } \\
\text { going deeper into a topic }\end{array}$ \\
\hline
\end{tabular}

$\left.{ }^{*}\right)$ The concepts were based on Renzulli, 2014b; Burns, 2014; Virgolim, 2014; Worrell et al., 2019. 
Access to an enriched environment that suits the educational and personal needs of the student with $\mathrm{HA} / \mathrm{G}$, implies offering a spectrum of possibilities in the most diverse areas of human knowledge so each one can fully develop their creative potential, autonomy and skills. An opposite environment is always problematic for the HA/G student who may become disinterested and lose motivation for studying (Hamza, Mohamed, \& Elsantil, 2020).

\subsection{Methodological Aspects}

The demands of current education request the development of teaching not only focused on the student, but also collaborative, related to everyday life, investigative and that enables the implementation of methodologies and practices that lead to the production of knowledge, critical and autonomous training.

Medeiros \& Goi (2020) state that changes in traditional teaching methods are necessary. It is necessary to allow the student to research, reflect, create hypotheses, test alternatives for meaningful learning. In this process, it is up to the teacher to mediate learning, encouraging the student to make use of their investigative, reflective and creative capacity.

In this scenario, the investigative methodology emerges as a strong ally in the teaching-learning process, allowing the development of practical activities, with concern for the student's cognitive aspect, the raising of hypotheses, analysis of results, argumentation and critical thinking (Mourão \& Sales, 2018; Baldaquim et al., 2018).

Therefore, this research uses the investigative methodology to implement a model of home enrichment, which creates a set of activities for teaching chemistry to children HA/G. The application used an experimental strategy of learning by playing and getting hands-on, to promote supplementation.

The activities worked on simple, everyday concepts in the field of chemistry, whose implementation was planned through four macro steps: raising questions and hypotheses, research and discussion of concepts, experimentation and conclusion. The interest in the topic and the active participation of the participants are fundamental characteristics of this model.

\section{Home Enrichment in the Chemistry Area}

Seeking an attractive, creative and motivating teaching environment, given the gaps left by many schools in Brazil and aware of the importance of an enriched environment, researchers develop a home enrichment model for the gifted, where it is possible to learn and play with topics of interest (Renzulli, 2014b; Ray, 2017; Musaddiq et al., 2021).

In this work, home enrichment is defined as the promotion of an enriched environment, at home, through a set of playful and educational activities, based on a main theme, working on skills and competences in the various areas of human knowledge (Renzulli, 2014b; Ray, 2017; Musaddiq et al., 2021). Based on this concept, the model was tested by using some chemical themes of interest of 
the children which participated in a research project. The concepts in the area of chemistry that were part of this chemistry project were: atoms, densities, homogeneous and heterogeneous systems, chemical reactions, physical transformations, pressure and decantation.

In this model for chemistry area, each concept was approached with guidance from parents and researchers in a work with activities researched, implemented, experimented, investigated and evaluated by two HA/G children aged 5 and 7 years. They were students from private schools of one of the biggest cities of Brazil. This chemistry project allowed to offer creative activities that allowed questions to be raised, as well as arguments and conclusions for each concept as described below.

\subsection{Atoms}

- Question(s): What are objects (things) formed of? What are you made of?

- Concept(s) Researched: Science says that everything is formed by small particles that bind together, called atoms. When atoms come together, they form molecules that constitute objects and people (Escola Brasil, 2021).

- Activity(ies): Using styrofoam balls, modeling clay and toothpicks, the children simulated atoms, molecules and the constitution of things in different shapes. They dealt in a concrete way with abstract concepts, created freely, debated about the importance, size and shape of atoms. Figure 1 illustrates the implementation of the atom and molecule activity performed by children.

- Conclusion(s): Answered the questions and used imagery in an attempt to visualize the shape and how small the atoms are.

\subsection{Densities}

- Question(s): Why do some objects sink and others float in water? Which objects sink and which float? Do the liquids behave the same?

- Concept(s) Researched: Science states that each material has its own density. Density represents the relationship between the amount of material and the volume of the object. The greater the density of the object, the greater the chance of it sinking (Nascimento et al., 2019).

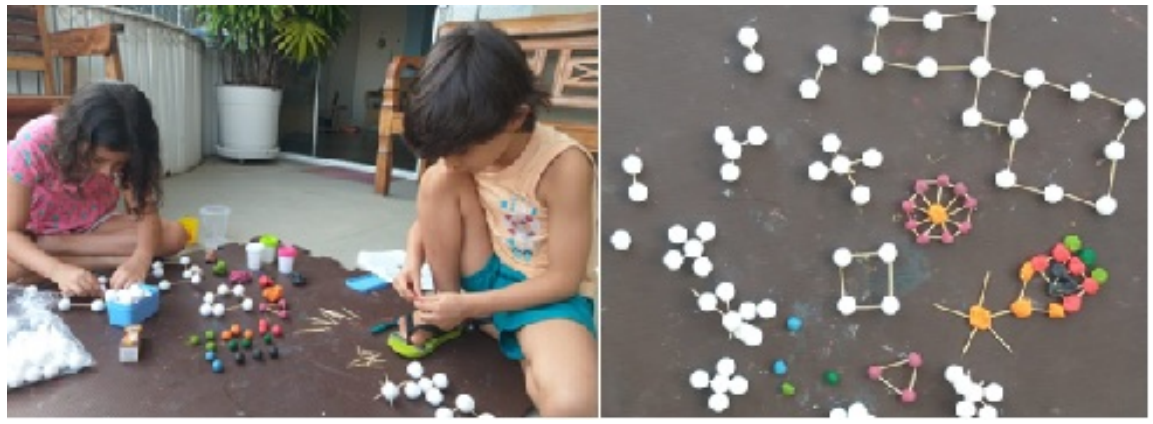

Figure 1. Atoms and molecules activity. 
- Activity(ies): Using a container with water and various objects chosen by the children (glue tube, pineapple, lemon, etc.) they started an experimentation process to see which objects sank and which ones floated in the water. Before each trial they anticipated what would happen, justifying their opinion. The activity was carried out with great enthusiasm by the children. The concept of density was also correlated with previously worked atoms and molecules.

Figure 2 illustrates the execution of the activity density of solids carried by children.

The experimental activity that contextualized this concept was performed by the HA/Gs showed by Figure 3. The activity carried out to work on the concept of density of liquids used water, oil, detergent, among others, as well as colorants of different colors and a transparent glass cup. The HA/G children performed the activity by dyeing the liquids, putting them in a transparent cup and noting that they did not mix due to the fact that they had different densities (Figure 3 ).

It is worth mentioning that the children were free to select different liquids and ended up observing that some of these substances mixed with others, due to their density. Despite of this observation be useful to reinforce the concept of density of liquids with the HA/G s, this fact caused discomfort on part of the participants-advisers, probably due to the unexpected outcome. This disconfourt was interesting to perceive as this is a common feeling on HA/G teachers that are caught by surprise with the acts and explanations of this public. This common behavior of these students requires further thinking and explanations and sometimes further preparation and studying from these teachers to attend them.

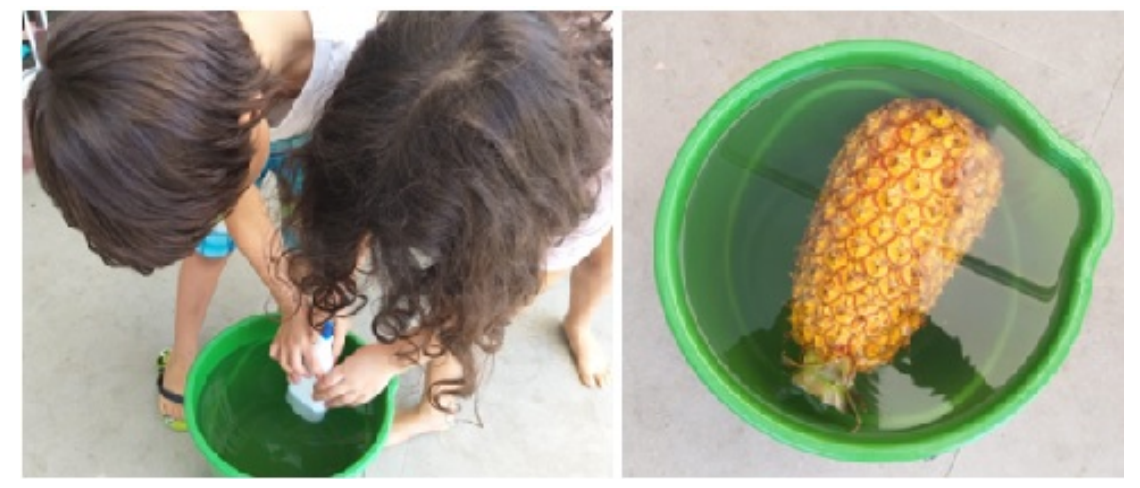

Figure 2. Density activity of solids.

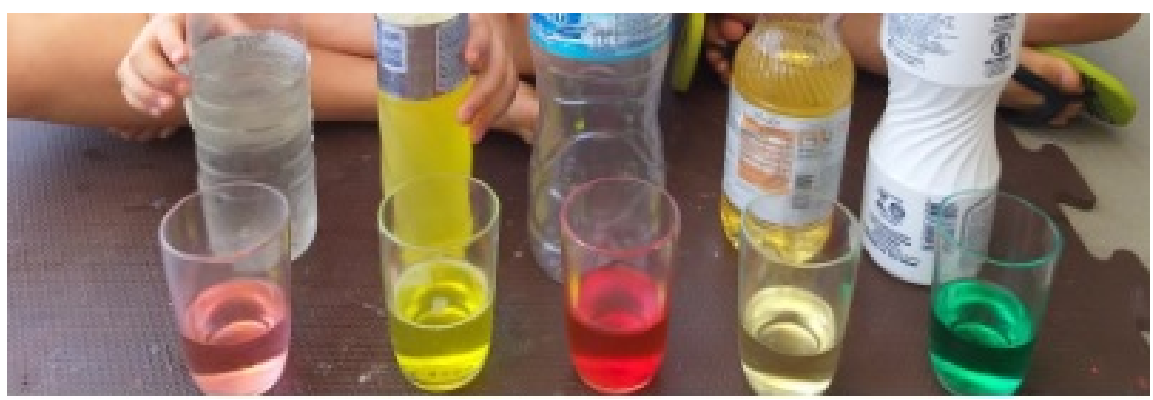

Figure 3. Liquid density activity. 
Another experiment was also carried out using two clear glass cups, two eggs, water and salt. The two cups were filled with water and then the eggs were added, whose chemical behavior was to sink. The salt diluted only in one of the glasses with the purpose of increasing the density of the water. It was found that in salted water the egg began to float as shown in Figure 4 (Nascimento et al., 2019).

\subsection{Homogeneous and Heterogeneous Systems}

- Question(s): What are systems? How does a homogeneous and a heterogeneous system appear?

- Research concept(s): Science states that most materials are made up of more than one type of mixed substance. Some of these mixtures, when observed, may appear as a single phase, with a uniform appearance, constituting homogeneous systems. Others are presented in more than one phase, with a non-uniform appearance, constituting heterogeneous systems (Yamamoto et al., 2018).

- Activity(ies): With the mixture of water and oil placed in a transparent glass container, it was possible to observe two phases in a heterogeneous system (Figure 5) and resume the discussion on the density of liquids.

- Conclusion(s): Answered the questions and appropriated in a concrete way the concepts of homogeneous and heterogeneous systems through the appearance of the mixtures performed.

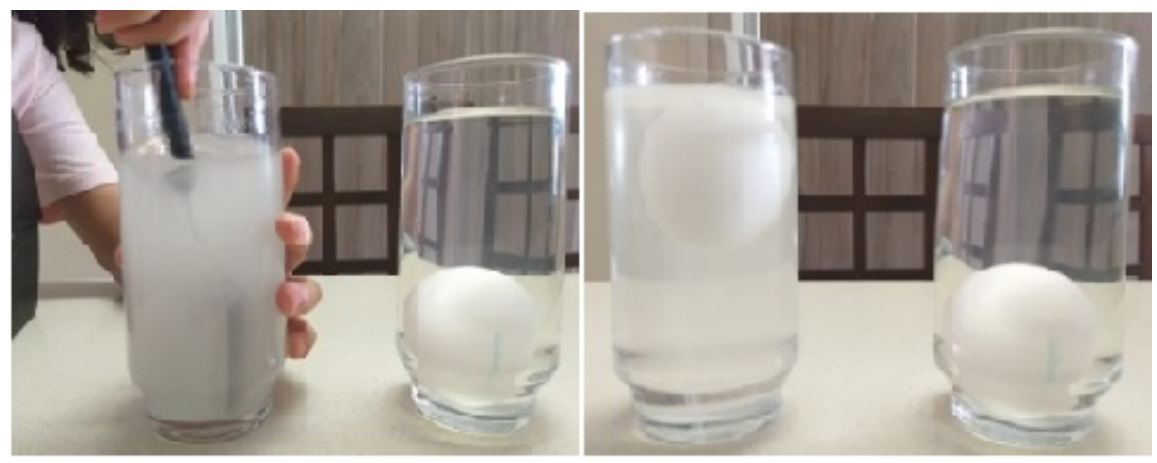

Figure 4. Density activity of solids and liquids.

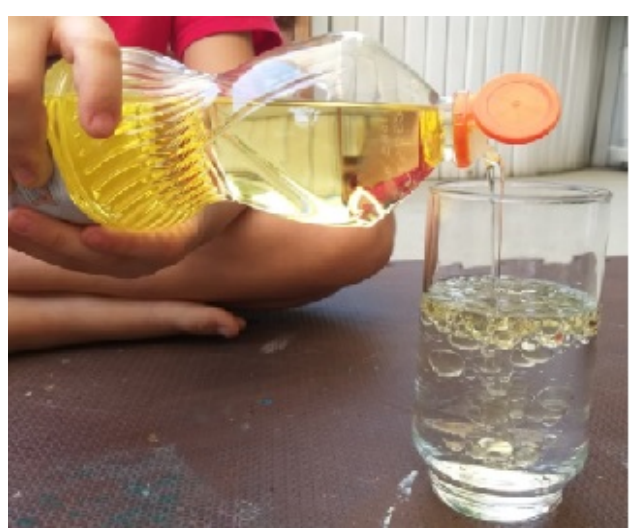

Figure 5. Heterogeneous system activity. 
Two experiments were performed: 1) the mixing of water and oil placed in a transparent glass container where it was possible to observe the two phases of a heterogeneous system (Figure 5), and 2) ingredients (butter, sugar, wheat flour and corn starch) were mixed to make cookies that ended with a tasty and fun snack. Such ingredients, after well mixed, generated a homogeneous mass with a uniform appearance that as widely discussed (Figure 6).

\subsection{Chemical Reactions}

- Question(s): What is a chemical reaction? How does a chemical reaction take place?

- Concept(s) researched: Science states that when a material has its substances transformed, a chemical reaction occurs, also called chemical transformation. In general, it is possible to notice that when a chemical reaction occurs, there is production of gas, light, heat, color change, among other phenomena (Yamamoto et al., 2018; Sales, Pereira and Araújo, 2021).

- Activity(ies): Simulation of an erupting volcano through a chemical reaction. For this, dyes in red and yellow, detergent, sodium bicarbonate and vinegar were mixed in a small PET bottle wrapped with modeling clay in brown (to look like the surface of a volcano). The mixture caused a chemical reaction between the substances and the children witnessed a small volcano erupting, spilling its larvae. The children's response was exciting and they wanted to repeat the experiment over and over again.

- Conclusion(s): They answered the questions and mixed substances that generated chemical reactions, appropriating the concept and noting that in everyday life we are surrounded by these transformations.

The activity carried out was the preparation of a cake by the children, from which it was possible to observe that the mixture of ingredients, associated with cooking, causes a chemical reaction and modifies the cake's ingredients, due to changes in color, flavor, odor and consistency. In this activity, during mass mixing, the concepts of homogeneous and heterogeneous systems were taken up (Figure 7).

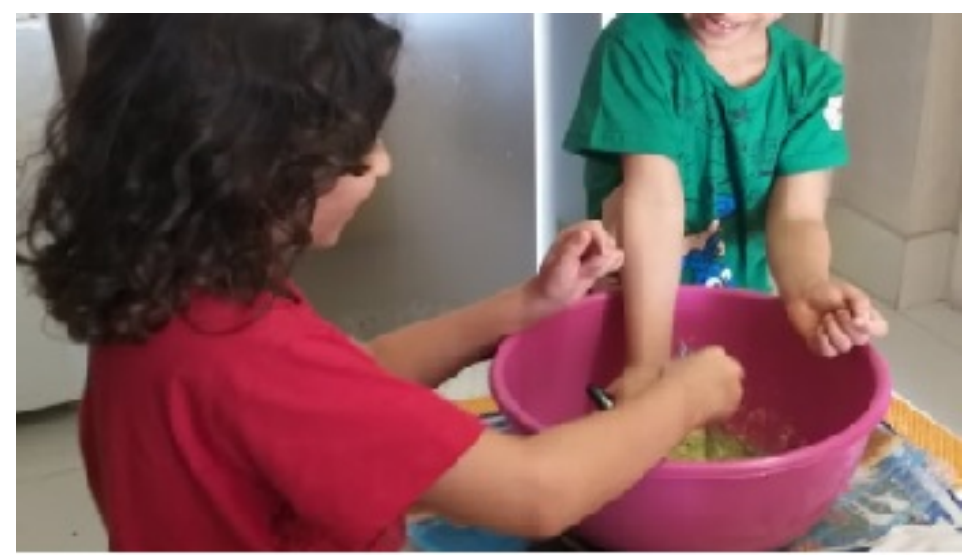

Figure 6. Homogeneous system activity. 


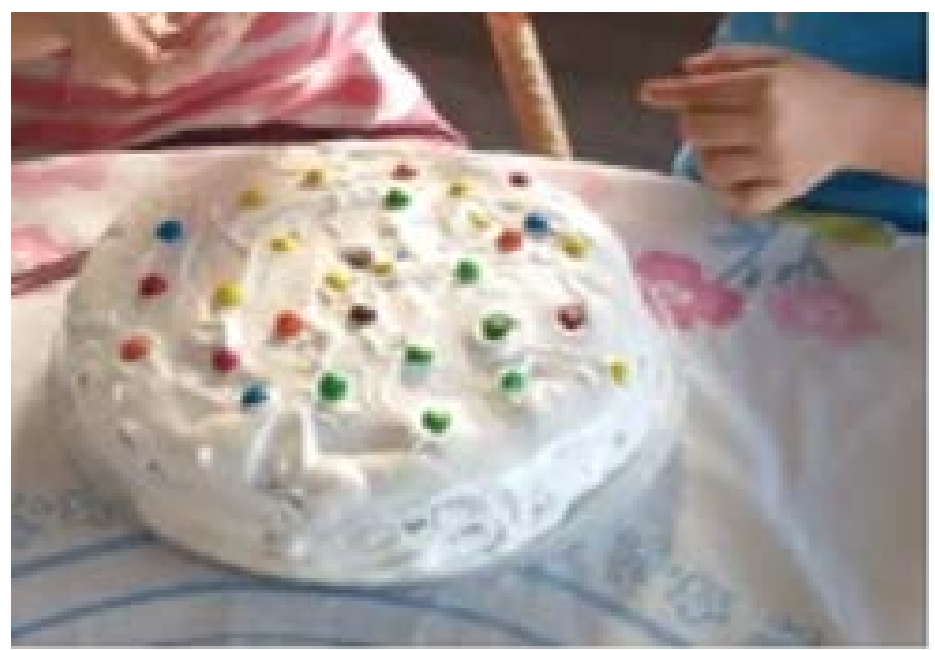

Figure 7. Chemical reaction activity.

\subsection{Physical Transformations}

- Question(s): What is physical transformation? How does a physical transformation take place? What is the difference between physical transformation and chemical transformation?

- Concept(s) researched: Science states that when a material undergoes transformations, but they do not modify its original substances, that is, there is no formation of new substances, a physical transformation occurs. Unlike the previous activity, whose ingredients reacted and created a cake, in the physical transformation, the production of new substance does not occur. A sheet of paper when crumpled can be considered a physical transformation, from which the paper underwent transformation, but did not generate any new substance (Yamamoto et al., 2018).

- Activity(ies): The experiment performed by the children to show the concept of physical transformations was to work on changes in the physical state of water (solid, liquid and gas). The children handled ice, water in its liquid state and observed it evaporate when heated (Figure 8). In this process, it was possible to study the concepts of solidification, fusion, vaporization, boiling and condensation.

- Conclusion(s): They answered the questions, promoted physical transformations and concluded that during this process the atoms and molecules are not modified, but messed up and rearranged again.

The experimental activity performed by the children in this concept was making fruit juice. Interestingly, they wanted to produce popsicles with the fruit juice after studying the physical state of the water. They were not authorized by their mother to make them as they had a cold and the study ended with many complaints by them.

\subsection{Pressure}

- Question(s): What is pressure? What effects of pressure? 


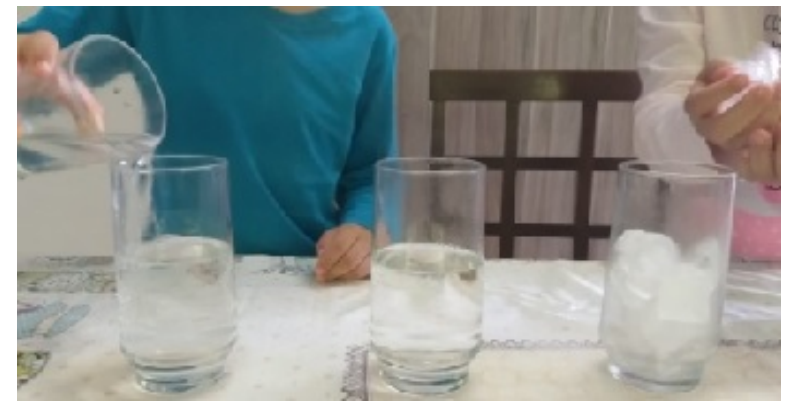

Figure 8. Physical state of water activity.

- Concept(s) researched: Science states that pressure is the ratio of the force applied perpendicularly to a surface, that is, the relationship between a force and its area of distribution. The less the area that receives the force, the greater the pressure exerted (Santos \& Silva, 2014).

- Activity(ies): Using a glass filled with water and a small piece of cardboard, the experiment was carried out as follows: the glass filled with water was covered with the cardboard, then just holding the cardboard firmly against the mouth of the glass, turn it upside down and then hold the glass by the bottom. With this procedure it was possible to observe that the glass, even upside down, remains covered by the cardboard and filled with water, the cardboard falls and the water spills.

- Conclusion(s): They answered the questions and observed the presence of pressure and its effects in daily life.

The experiment for this concept was by using a PET bottle filled with water and a small hole. When squeezing the bottle, that is, exerting force under the surface, the water comes out with pressure through the small hole. The next moment, with the same bottle and now a larger hole, it is observed that the water comes out with less pressure (Figure 9).

It was also discussed how the pressure cooker works and why food cooked faster with it; the behavior of the straw when drinking liquids, among other issues.

\subsection{Decanting}

- Question(s): What is decanting? What is decanting for?

- Concept(s) researched: Science states that decanting is the process of separating heterogeneous mixtures, of the type, for example, liquid-liquid or liquid-solid, based on the difference in density of materials (Santos and Silva, 2014).

- Activity(ies): Water and sand were mixed in a clear glass. After a few minutes of standing, the mixture was decanted. It was observed that the sand, due to its density greater than water, is visibly separated from it at the bottom, in a heterogeneous system (Figure 10). It was possible to separate the water and sand into different containers after decanting. The importance of decanting was debated, as an example with the extraction of salt from sea water. 


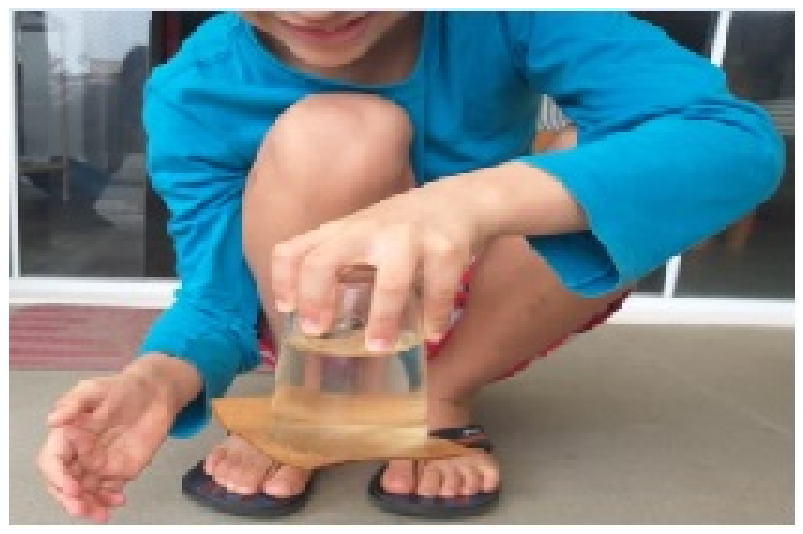

Figure 9. Pressure activity.

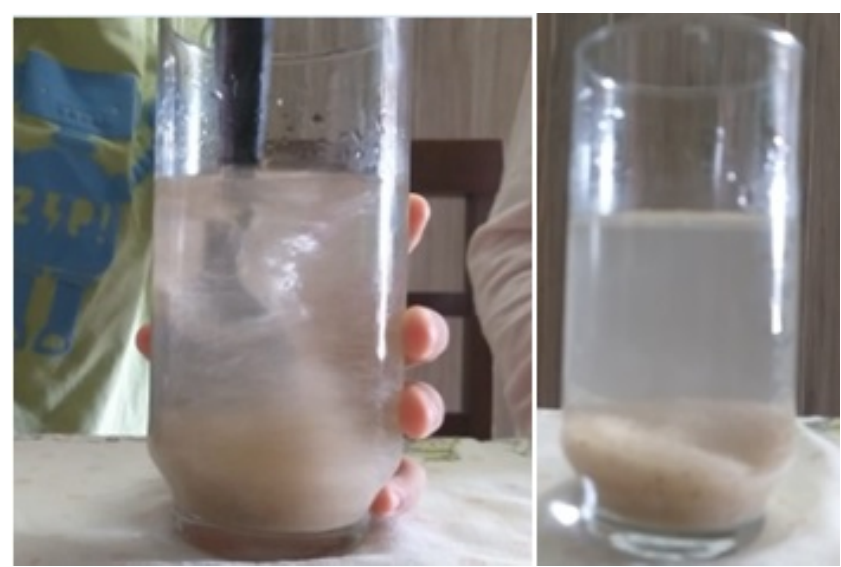

Figure 10. Decanting activity.

- Conclusion(s): Answered the questions and critically analyzed the importance and usefulness of decanting.

All activities performed and described above in the home enrichment process in the area of chemistry fall into type I and II of the triardic model by Renzulli (2014b).

An evaluation form was designed to verify the children's acceptance of each activity of the "chemistry" project, as well as to guide future projects. The form was applied at the end of each concept worked, individually to the participants. It brings the applied concepts and a gradation (good, regular and bad), where each child will indicate if they liked it; he found himself regular; or if you didn't like the work related to each content. At the end, there is an observation field to justify any possible response, if deemed necessary.

Figure 11 shows the ratings obtained with the two children AH/S participating in the home enrichment process in the chemical area. In the graph, it is observed that no theme worked received a bad evaluation. Only the subject of physical transformations was rated by one of the children as regular. The justification for this dissatisfaction was given by the mother's prohibition on making popsicles. All other concepts worked received maximum evaluation by the participants. 


\section{Home Enrichment - Chemical Project Assessment}

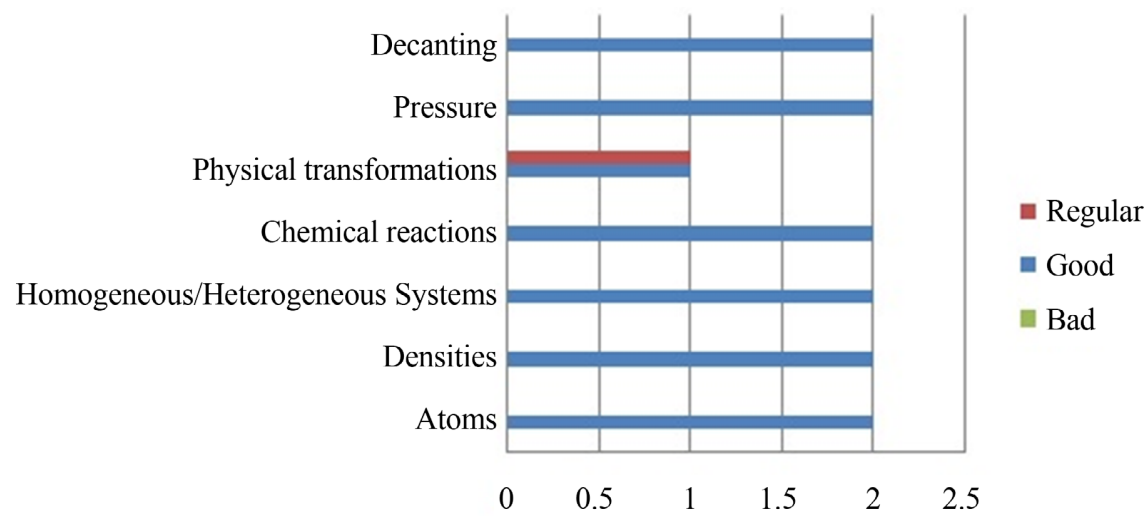

Figure 11. Evaluative responses of participating children.

In the field observations of the evaluation form, one of the children commented that the liquid density experiment did not work as expected. Some liquids ended up mixing with others due to their density. Another observation that appeared in the evaluation process mentioned the continuity of the household enrichment process, as well as the suggestion of new topics of interest.

Throughout the entire application, the children are actively involved, researching, suggesting, selecting material, raising questions, arguing and even criticizing. Learning took place in a participatory, autonomous, motivational, pleasurable and meaningful way.

\section{Conclusion}

Schools worldwide are failing on providing educational assistance to HA/G students. The educational system in countries in development such as Brazil should be aware of the importance of an enriched teaching environment for this public mental well being and their educational development. Due to the COVID-19, home has now been considered as a place to learn together with children schools. Based on this scenario and focusing on making home a place that may work together with these schools also in the perspective of HA/Gs, we developed a simple model of home enrichment for these HA/Gs, seeking autonomous, motivating, investigative and student-focused learning. Importantly, our model allows working, at home, on skills and competences in various areas of interest, through a set of playful and educational activities, based on a main theme.

This article described the application of this home enrichment model in the field of chemistry applied to two Brazilian children, with HA/G, aged 5 and 7 years. It is worth mentioning that the application of this model does not require great planning or long time of their parents or even expensive resources. In fact the set of activities carried out in the chemical project described in this article shows the use of accessible and everyday resources. The concepts worked on are also simple and frequent in our daily lives showed in an uncomplicated way.

Throughout the process, the children were motivated, collaborative, creative 
and investigative, making comments, making reflections, arguments, raising hypotheses, bringing ideas and suggestions, really involved in the ludic learning process. The results demonstrate the viability of home enrichment, promoting significant learning, showing promise, and motivating the desire to expand the proposal. This model maybe multiplied and used to approach other knowledge areas. It is focused on attending HA/Gs but it also allows to be used to inspire girls and boys to the area of chemistry as well.

\section{Conflicts of Interest}

The authors declare no conflicts of interest regarding the publication of this paper.

\section{References}

Baldaquim, M. J. et al. (2018). A experimentação investigativa no ensino de química: Construindo uma torre de líquidos. ACTIO: Docência em Ciências, 3, 19-36. https://periodicos.utfpr.edu.br/actio/article/view/6835 https://doi.org/10.3895/actio.v3n1.6835

Brasil. Lei de Diretrizes e Bases da Educação-LDB (1996). Lei $N^{\circ} 9.394$ de 20 de dezembro de 1996. Brasília, DF.

Brasil. Lei de Diretrizes e Bases da Educação-LDB (2013). Lei $N^{\circ} 12.176$ de 4 de abril de 2013. Brasília, DF.

Brasil. Lei de Diretrizes e Bases da Educação-LDB (2015). Lei $N^{\circ} 13.168$ de 6 de outubro de 2015. Brasília, DF.

Brasil. Ministério da Educação (2001). Resolução CNE/CEB $N^{\circ} 02$ de 11 de setembro de 2001. Brasília, DF.

Burns, D. E. (2014). Altas habilidades/superdotação: Manual para guiar o aluno desde a definição de um problema até o produto final. Juruá Editora.

Conejeros-Solar, M. L., \& Smith, S. R. (2021). Homeschooling Gifted Learners: An Australian Experience. Australasian Journal of Gifted Education, 30, 23-48.

de Alencar, E. S., \& Martins, A. da C. S. (2011). Características desejáveis em professores de alunos com altas habilidades/superdotação. Revista Educação Especial, 24, 31-46. https://doi.org/10.5902/1984686X1881

Escola Brasil (2021). Átomo. https://brasilescola.uol.com.br/o-que-e/quimica/o-que-e-atomo.htm

Gardner, H. (1993). Estruturas da Mente: A Teoria das Inteligências Múltiplas. Artes Médicas.

Gardner, H. (1999). Inteligência: Um Conceito Reformulado. Objetiva.

Garofalo, D. (2018). Que habilidades deve ter o professor da Educação 4.0. https://novaescola.org.br/conteudo/11677/que-habilidades-deve-ter-o-professor-da-ed ucacao-40

Hamza, E. G., Abo Mohamed, E., \& Elsantil, Y. (2020). A Systemic Review Based Study of Gifted and Talented. Talent Development \& Excellence, 12, 2888-2897.

Hussin, A. A. (2018). Education 4.0 Made Simple: Ideas for Teaching. International Journal of Education \& Literacy Studies, 6, 92-98.

Kueth, J. (1978). O processo ensino-aprendizagem. Editora Globo.

Martins, F. R., Cardoso, F. S., \& Delou, C. M. C. (2016). Clube de ciências: Atendimento a 
alunos com superdotação. Journal of Research in Special Educational Needs, 16, 299-302. https://doi.org/10.1111/1471-3802.12292

Medeiros, D. R., \& Goi, M. E. J. (2020). A resolução de problemas como uma metodologia investigativa no ensino de ciências da natureza. Research, Society and Development, 9, 1-32.

Moran, J., \& Bacich, L. (2018). Metodologias ativas para uma educação inovadora: Uma abordagem teórica-prática. Penso.

Mourão, M. F., \& Sales, G. L. (2018). O uso do ensino por investigação como ferramenta didático-pedagógica no ensino de física. Experiências em Ensino de Ciências, 13, 428-440. https://if.ufmt.br/eenci/artigos/Artigo_ID549/v13_n5_a2018.pdf

Much, M., Liane, N., Bonfada, K. M., \& Terrazzan, E. A. (2018). Mudança na prática docente: Incentivando o protagonismo discente. Revista Latino-Americana de Estudios en Cultura y Sociedad/Latin American Journal of Studies in Culture and Society, 4, 1-9. https://periodicos.claec.org/index.php/relacult/article/view/805/441

Musaddiq, T. et al. (2021). The Pandemic's Effect on Demand for Public Schools, Homeschooling, and Private Schools. NBER Working Paper No. 29262.

https://www.nber.org/papers/w29262 https://www.nber.org/system/files/working_papers/w29262/w29262.pdf

Nascimento, I. D. S. et al. (2019). Portfólio de experimentos para o ensino de química básica na formação farmacêutica. Revista Arquivos Científicos (IMMES), 2, 101-110. https://doi.org/10.5935/2595-4407/rac.immes.v2n2p101-110

Panagiotopolos, G. A., \& Karanikola, Z. A. (2020). Education 4.0 and Teachers: Challenges, Risks and Benefits. European Scientific Journal, 16, 114-128. https://doi.org/10.19044/esj.2020.v16n34p114

Passarelli, B., Junqueira, A. H., \& Angeluci, A. C. B. (2014). Os nativos digitais no Brasil e seus comportamentos diante das telas. Matrizes, 8, 159-178. https://doi.org/10.11606/issn.1982-8160.v8i1p159-178

Peres, M. R. et al. (2013). A formação docente e os desafios da prática reflexiva. Educação, 38, 289-304. https://doi.org/10.5902/198464444379

Petrie, C. (2020). Spotlight: Quality Education for All during COVID-19 Crisis (Hundred Research Report\#01). United Nations.

https://hundred-cdn.s3.amazonaws.com/uploads/report/file/15/hundred_spotlight_cov id-19_digital.pdf

Ray, B. (2017). A Review of Research on Homeschooling and What Might Educators Learn? Pro-Posições, 28, 85-103. https://doi.org/10.1590/1980-6248-2016-0009 https://www.scielo.br/j/pp/a/ZTmFNFsGTXjjzn4W43MKwXJ/?format=pdf\&lang=en

Renzulli, J. (2014a). A concepção de superdotação no modelo dos três anéis: Um modelo de desenvolvimento para a promoção da produtividade criativa. In A. M. R. Virgolim, \& E. C. Konkiewitz (Eds.), Altas habilidades/superdotação, inteligência e criatividade: Uma visão multidisciplinar (pp. 219-264). Papirus.

Renzulli, J. (2014b). Modelo de enri quecimento para toda a escola: Um plano abrangente para o desenvolvimento de talentos e superdotação. Revista Educação Especial, 27, 539-562. https://doi.org/10.5902/1984686X14676

Renzulli, J. S. (1986). The Three-Ring Conception of Giftedness: A Developmental Model for Creative Productivity. In J. S. Renzulli, \& S. M. Reis (Eds.), The Triad Reader (pp. 55-86). Creative Learning Press.

Renzulli, J. S., \& Reis, S. M. (1997). The Schoolwide Enrichment Model: A How-to Guide for Educational Excellence. Creative Learning Press.

Sabatella, M. L., \& Cupertino, C. M. B. (2007). Práticas educacionais de atendimento ao 
aluno com Altas Habilidades/Superdotação. In D. D. S. Fleith (Ed.), A construção de práticas educacionais para alunos com altas habilidades/superdotação (pp. 67-80). SEESP/MEC.

Sales, P. F. D., Pereira, R. A., \& Araújo, R. L. D. (2021). Química para crianças: Aprendendo química de um jeito diferente (1st ed., 32 p). Bambuí. https://educapes.capes.gov.br/bitstream/capes/586635/2/Qu\%C3\%ADmica\%20para\%2 0crian\%C3\%A7as_aprendendo\%20qu\%C3\%ADmica\%20de\%20um\%20jeito\%20diferen te.pdf

Santos, C. L. R. D., \& Silva, J. R. R. T. D. (2014). A química no nosso dia a dia: Química para crianças (1st ed.). Núcleo de Instrumentação Didática.

Souto, K. C., Castro, H. C., \& Delou, C. M. C. (2021). Da formação básica à prática docente: Qual à percepção do professor sobre a superdotação? Travessias, 15, 369-388. https://doi.org/10.48075/rt.v15i2.26215

Virgolim, A. M. R. (2014). A contribuição dos instrumentos de investigação de Joseph Renzulli para a identificação de estudantes com Altas Habilidades/Superdotação. Revista Educação Especial, 27, 581-610. https://doi.org/10.5902/1984686X14281

Worrell, F. C. et al. (2019). Gifted Students. Annual Review of Psychology, 70, 551-576. https://www.gwern.net/docs/iq/smpy/2019-worrell.pdf https://doi.org/10.1146/annurev-psych-010418-102846

Yamamoto, A. C. D. A. et al. (2018). Buriti Plus Ciências (1st ed.). Editora Moderna. 